Review

\title{
A global systematic review on biology, production constraints and uses of Cyperus exculentus L. (Neglected and Underutilized Crop Species): implications for valorization.
}

\author{
Ghislain Comlan Akabassi ${ }^{*}$, Kofi Kibalou Palanga ${ }^{2}$, Elie Antoine Padonou ${ }^{3}$, Yao Dodzi Dagnon ${ }^{4}$, Koffi Tozo $^{4}$, \\ Achille Ephrem Assogbadjo ${ }^{1}$
}

1Laboratory of Applied Ecology, University of Abomey Calavi, Abomey Calavi, Cotonou, Benin

2Institut Supérieur des Métiers de l’Agriculture, Université de Kara (ISMA-UK), Kara, Togo

3School of Tropical Forestry, National University of Agriculture, Porto Novo, Benin.

4Laboratoire de Biotechnologies, Physiologie et Biologie Moléculaire Végétales, Faculté des Sciences, Université de Lomé, Togo

${ }^{*}$ Correspondence: cgakabassi@gmail.com

\begin{abstract}
Food security relies mainly on a few major crop such as wheat, maize, rice and yam. Many of the cultivated plant such as Cyperus exculentus are still considered invasive plants and are neglected and underutilized. In the perspective to valorization of the species, this systematic review aimed at identifying the biology, production constraints and uses of tigernut for future research directions. Extensive searches were carried out and studies were screened and extracted using established systematic review methods. A total of 175 papers met the inclusion criteria. Approximately $52 \%$ and $21.71 \%$ of the studies were undertaken in Europe and Africa respectively. Most of the papers reviewed for the study were published between [2010-2015[. The review highlighted the critical research gaps in genetic diversity using SSR makers and evolutionary biology. Further, production constraints and solution approaches for the promotion of the species were the other gaps identified in the reviewed studies. Production constraints were specifically related to the insufficient mineral fertilizers and difficult in harvesting. Tigernut is used in more fields such as food, medicinal, cosmetic, biofuel and fishing and fish breeding. Such investigations would help in decisionmaking and elaboration of breeding strategies, and advancing steps towards sustainable use of the species.
\end{abstract}

Keywords: Cyperus exculentus; Neglected/Underutilized Crop species; Biology; Uses; Production constraints

\section{Introduction}

Today, despite the fact that several national and international institutions are joining their efforts to reach out the objective of "zero hunger" in the world (Sustainable Development Goal 2); many localities in the world, especially developing countries, continue to suffer from the problem of malnutrition. Food insecurity continues to withstand and many people around the world are dying every day owing to lack of daily food. More attention must be paid to agricultural diversification because a lot of plant species (sources of important nutrients) and arable land still remain untapped. Food security relies mainly on a few major crop species such as wheat, maize, rice, cassava and yam. 
Many of the cultivated plant species are neglected and underutilized as they play a crucial role in the food security, nutrition, and income generation of the poor rural people [1-3]. These Neglected and Underutilized Crop Species (NUCS), also known under the name of minor cultures or "orphan plant", represent an untapped reservoir of genetic and functional diversity and are able to contribute to food security and poverty reduction [2]. Lack of attention and research studies about the NUCS means that their potential value is underestimated and underexploited. According to reports from the Food and Agriculture Organization (FAO), since the 1900s about 50-77\% of plant genetic diversity has been lost. The main causes for this remain economic, social and demographic factors. The studies of Johns and Eyzaguirre [4] and Ghane et al. [5] showed that NUS are nutritionally rich therefore, their erosion can impact the nutritional status and food security of the poor and their enhanced use can bring about better nutrition and fight hidden hunger.

Among NUCS, tigernut (Cyperus esculentus L.) is listed [2, 6-9]. Tigernut is an herbaceous plant of the cyperaceae plant family (Figure 1a, b, c), native to the Mediterranean and eastern Asia [10]. Its yellow rhizomes form small tubers that turn yellowish-brown when ripe (Fig. 1d). It has been domesticated and used as a food plant almost in all continents (Africa, Southern Europe, Asia and Northeastern USA) of the world [11-13]. Tigernut is not a nut but a small tuber (Figure 1e) very rich in fiber, proteins and natural sugars. Tigernut tubers contain a significant amount of protein, fatty acid, amino acid, minerals and vitamins $[14,15]$. The tubers with a slightly sweet, nutty flavour, are edible compared to bitter-tasting tuber of the related purple nutsedge (Cyperus rotundus). Tigernut has been domesticated and used as a food plant in many parts of the world such as Spain where it is consumed as a milky drink [16]. It is also cultivated and sold in China, North and West Africa (Ghana, Nigeria, Niger, Burkina Faso (Figure 1f), Mali, Ivory Coast) [17] and in the USA [11]. Tigernut tubers are used for the treatment of certain ailments such as indigestion, diarrhea, dysentery, gas, and excessive thirst [18]. In addition to its medicinal properties tigernut is also used as fishing bait and since the tubers contain a reasonable percentage of oil, it has been suggested as a possible source of biodiesel [19-21].

Despite the economic and nutritional importance of the species, its cultivation is often abandoned to women and / or practiced in small spaces. In Africa, its cultivation is practiced only in a few countries while it is recorded to be adapted to difficult environments unfit for other crops where they can provide sustainable productions. To promote its use and maximize its economic value, conservation, and research on this neglected species is needed for better maintenance of it resource base, to ensure its development and its sustainable use by present and future generations. To enhance the value of the tigernut industry, an inventory is essential in order to identify the problems that hinder its development, and to understand the causes of neglect and underutilization of culture. It is with this in mind that the present review has been undertaken to constitute a database on biology, production constraints and uses of tigernut (Cyperus exculentus L.). Firstly, origin, biology, ecology and distribution of tigernut have been documented using an approach based on literature review. Secondly, using the same methodology, the main constraints that prevent the farmers from adopting this crop have been inventoried. And then the uses of tigernut have been documented in order to identify research topics necessary for the development of the sector. Some solution approaches have been introduced to neutralize the production constraints of tigernut. 

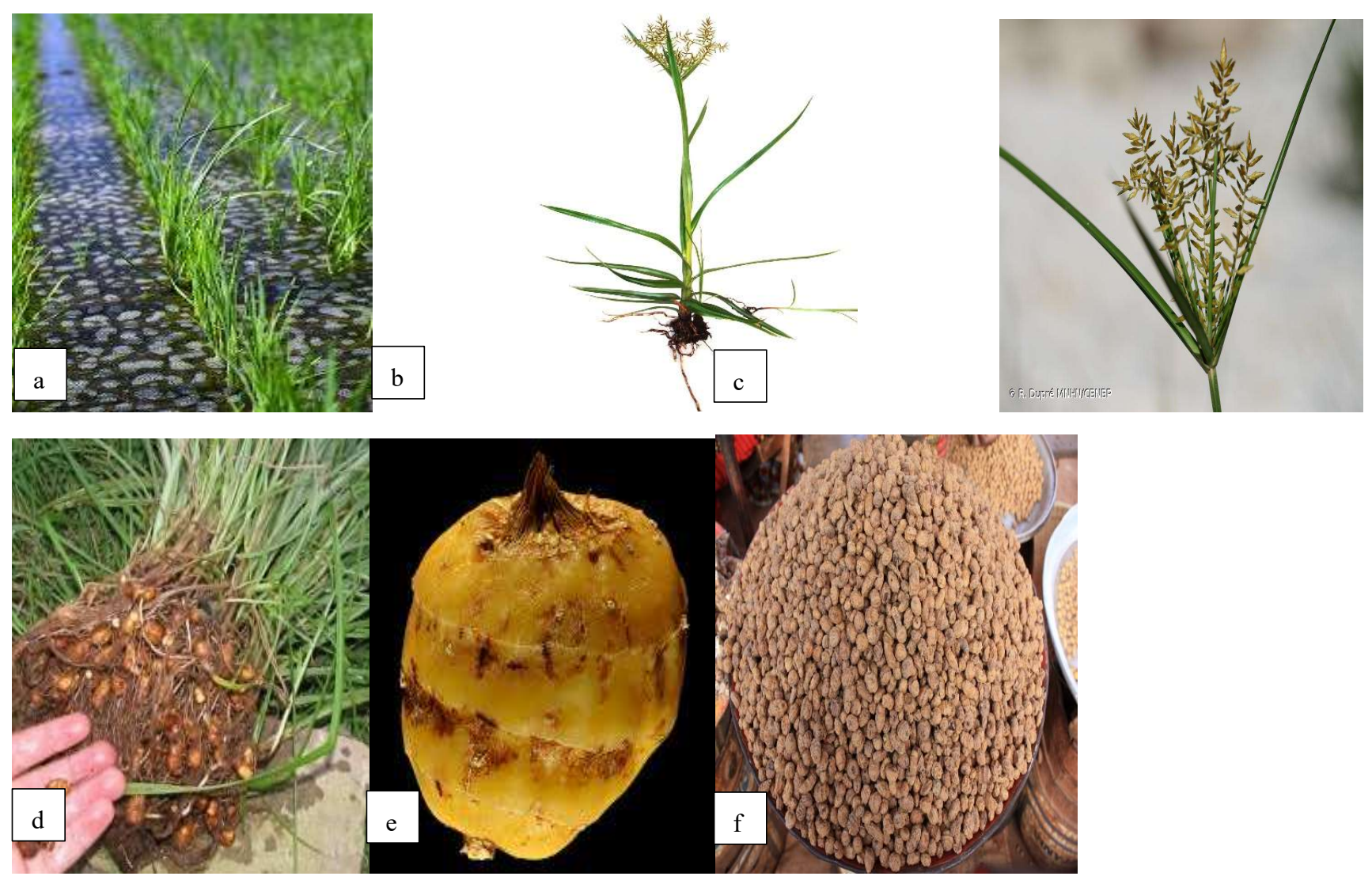

Figure 1. Details of the Cyperus exculentus plant species. a Seedlings of C. exculentus. b C. exculentus plant in the flowering stage. c C. exculentus inflorescences. $d$ ripeness of $C$. exculentus tubers ready for harvest. The mature tuber of C. exculentus. $f$ Dried C. exculentus tubers ready for sale.

\section{Research method}

\subsection{Literature search approach}

The literature review was embedded in a wider review, which included tigernut, Cyperus exculentus, yellow nutsedge, Sweet nutgrass, Earth almond, Sultan nutgrass, chufa, and "Tchongon and incorporated qualitative, quantitative and case studies. The scientific papers, Thesis (Master and $\mathrm{PhD}$ ) and official reports on $\mathrm{C}$. exculentus were obtained from various databases including Google Scholar (www.scholar.google.fr), ScienceDirect (www.sciencedirect.com), and African Journals Online (www.ajol.info). During the search, publications over 40 years from 1980 to 2020 were considered and the words used for the review included "biology", "ecology", "distribution", " origin", " usages", "production constraints", "neglected/underutilized crop species", "orphan crop", "yield production" in combination with each of these words "Souchet", "tigernut", "Cyperus exculentus", "yellow nutsedge", "Sweet nutgrass", "Earth almond", "Sultan nutgrass", "chufa", "Tchongon".

\subsection{Inclusion/Exclusion Criteria and Screening Studies}

Search results were screened for all databases using titles, abstracts and keywords of the publications. Letters, encyclopaedia, books, manuals and guidelines were excluded. 
Four For final inclusion in the review, all publications were screened using 11 established criterion adapted from Harden et al. [22] reflecting: (a) importance of reporting; (b) use of strategies to set up reliable data collection and analysis for the validity of the findings; and (c) the extent to which findings reflect participant perspectives and experiences. All papers recorded were classified in three categories. It considered as strong with 9-11 criteria, moderate with 5-8 criteria or weak with 1-4 criteria.

The information compiled on the publications retained for this review were (i) journal and title of the publication; (ii) keywords of the publication (iii) year of the publication; (iv) country of the study and continent; (v) study location within country; (vi) full reference and aspects point out in the study have to be either of the following: (a) uses; (b) socio-economic importance; (c) morphological diversity; (d) reproductive biology; (e) ecophysiology aspects; (f) growth and development; (g) production and harvest; (h) genetic diversity; genetic erosion of $C$. exculentus or with different name abovementioned. Final retained publications were read in detail to summarize the available information based on the mean and percentage.

\subsection{Selection and Characteristics of publications}

The overall search identified 891 publications. Out of these, 403 publications (studies with records excluded, studies with records not obtained) were excluded during the screening and refining steps. 300 eligible publications were thus considered for full text screening, a process out of which a total of 175 publications (53 in ScienceDirect, 91 in Google Scholar, 31 in AJOL), were finally included in the systematic review (Figure 2). Of these, 135 were qualitative studies concerned with biology, production constraints and uses of tigernut and therefore met the inclusion criteria for this review, 32 were quantitative studies and 08 were case studies.

These 175 studies were published over four decades (1980 - 2020), as considered for this review, and in 91 journals with 32, 42, and 16 publications identified by ScienceDirect, Google Scholar and AJOL respectively (Figure 3).

In the strong (90 papers) and moderate (30 papers) studies, context of the study, problem, description of sampling and methods used to collect the data were clearly explained. However, there was not always enough information given about data analysis to increase validity and reliability. While there was some limitations in the amount of quotes presented, in most studies there were sufficient to verify the findings. The study identified as weak (15), did not present any of the qualitative data on which the findings were based making it more difficult to assess validity.

\section{Results}

\subsection{Selection and Characteristics of publications}

The overall search identified 891 publications. Out of these, 403 publications (studies with records excluded, studies with records not obtained) were excluded during the screening and refining steps. 300 eligible publications were thus considered for full text screening, a process out of which a total of 175 publications (53 in ScienceDirect, 91 in Google Scholar, 31 in AJOL), were finally included in the systematic review (Figure 2). Of these, 135 were qualitative studies concerned with biology, production constraints and uses of tigernut and therefore met the inclusion criteria for this review, 32 were quantitative studies and 08 were case studies. 
These 175 studies were published over four decades (1980 - 2020), as considered for this review, and in 91 journals with 32, 42, and 16 publications identified by ScienceDirect, Google Scholar and AJOL respectively (Figure 3).

In the strong (90 papers) and moderate (30 papers) studies, context of the study, problem, description of sampling and methods used to collect the data were clearly explained. However, there was not always enough information given about data analysis to increase validity and reliability. While there was some limitations in the amount of quotes presented, in most studies there were sufficient to verify the findings. The study identified as weak (15), did not present any of the qualitative data on which the findings were based making it more difficult to assess validity. 


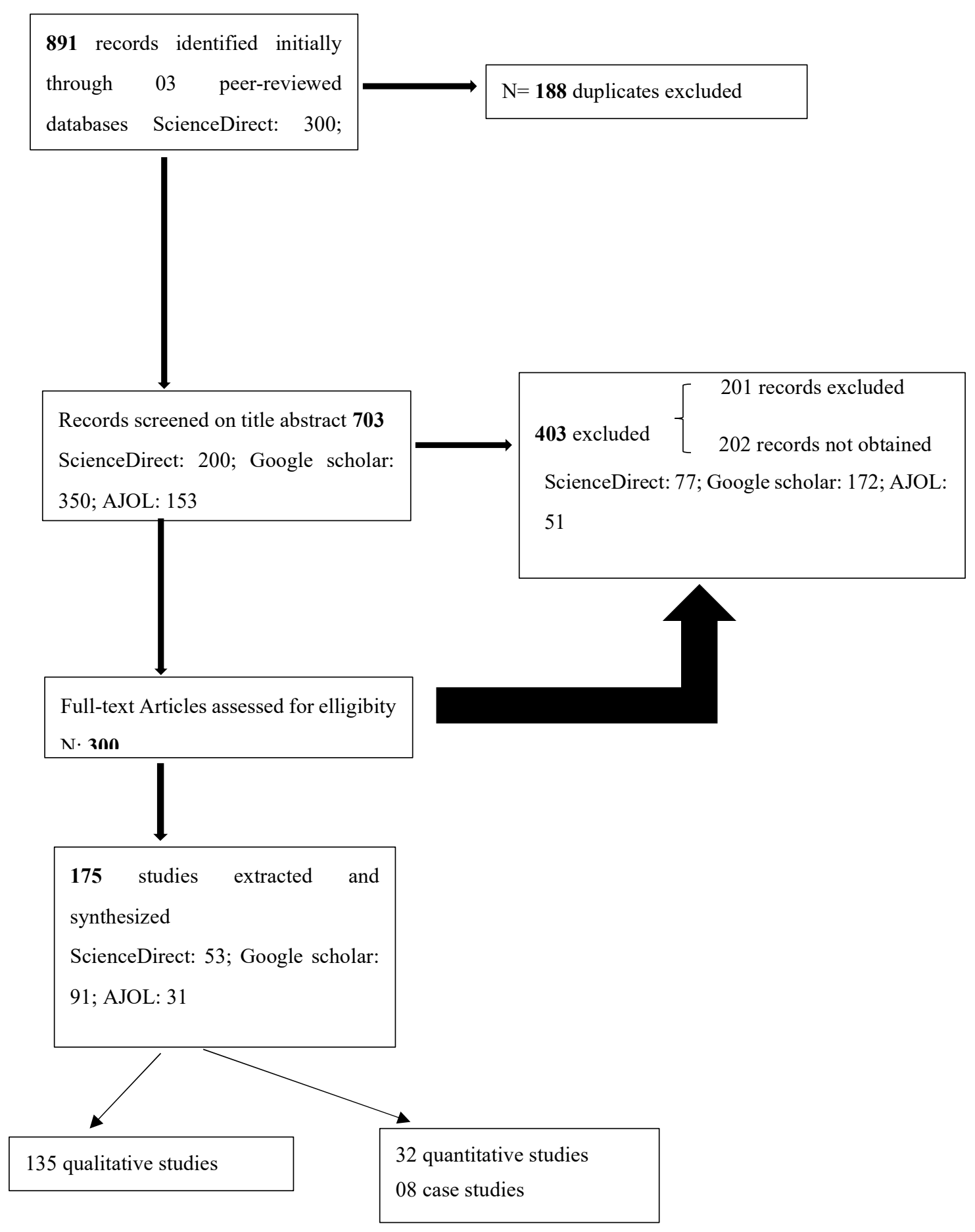

Figure 2. Flowchart of search results on biology, production constraints and uses of Tigernut. 


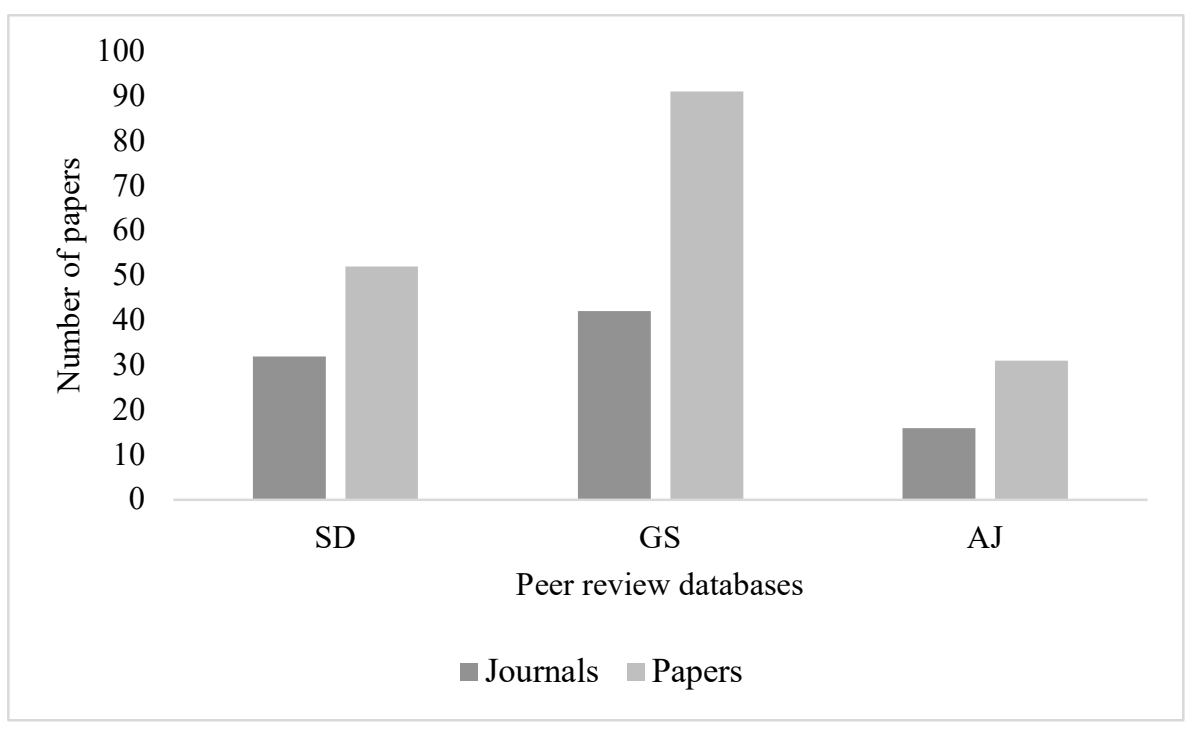

Figure 3. Number of journal and recorded papers on biology, production constraints and uses of Tigernut.

SD: Science Direct; GS: Google Scholar; AJ: African Journals Online (AJOL).

\subsection{Spatio-temporal patterns}

Over four-decades, the number of papers dealing with biology, constraint productions and uses of tigernut increased generally each five year period (Figure 4). About $54.14 \%$ of the papers included in this review were published from 2005 to 2020 . The highest number of papers $(n=44)$ was recorded between [2010-2015 [while the lowest $(n$ =5) between [1980-1985[. The 175 publications came from the four continents of the world. Most of these publications were from Europe $(n=91)$, followed by America $(n=$ $38)$, and Africa $(n=34)$ and Asia $(n=12)$ (Figure 5). Most publications focused on traditional uses and biochemical composition, and transformation of tigernut tuber. As compared to the traditional use, there were fewer studies on structural characteristics, threats and production constraints, and socio-economic aspects. Aspects such as morphological diversity, ecophysiology, genetic diversity and production yield were little investigated. This review showed that research on conservation biology and uses of the species has increased substantially over the two last decades. The reason for this research interest in C. exculentus could be found in the global trend in research funding that is mainly concerned about the valorization on Neglected/Underutilized Crop Species (NUCS). For instance, Regional Universities Forum for Capacity Building in Agriculture (RUFORUM) in collaboration with Bioversity International and four universities located in Benin, Ghana, Kenya, and Malawi had launched in 2010 a project entitled "building human and institutional capacity for enhancing the conservation and use of Neglected and Underutilized Species of crops in West Africa, and Eastern and Southern Africa". This project has substantially boosted research on neglected cultures and today, many cultures considered as unimportant culture are being promoted. It's the case of Macrotyloma geocarpum (Harms) Marechal \& Baudet, Vigna subterranean (L.) Verdc., Launaea taraxacifolia (Willd.) Amin ex C. Jeffrey, Ipomoea batatas (L.) Lam., Cajanus cajan (L.) Millsp., Dioscorea dumetorum (Kunth) Pax, Parkia biglobosa (Jacq.) R. Br. ex Benth., Cleome gynandra L. etc. 
$52 \%$ of papers were from Europe and $21.71 \%$ from America while $18.28 \%$ from Africa, suggesting lower research effort in Africa on the NUCS, as compared to other regions. This situation shows that research on NUCS in Africa is very recent and efforts must be increased in order to save the genetic resources of these species. Indeed, these Neglected and Underutilized Species are able to contribute to food security and poverty reduction [2, 4, 5]. In Africa, most of the scientific papers on C. exculentus were from West Africa and three first countries were Nigeria, Niger and Ghana, suggesting greater research effort in this sub-region, as compared to North, Central and East Africa. This trend could be explained by the intensive use reported for the species in West Africa [2, $15,23,24]$. Indeed, most of the papers in West Africa addressed traditional uses and socio-economic aspects. Two main reasons could justify the relative difference of publications between North, West, Central and Eastern Africa on C. exculentus. Firstly, it is probably because of unequal research funds granted across these sub-region in Africa on NUCS. Secondly, it may also be due to the fact that the species population is more distributed in West Africa countries, than in North, Central and East Africa. This may also reflect gaps in search literatures and documentation of many aspects of domestication, conservation and valorization of $\mathrm{C}$. exculentus in these three sub-regions.

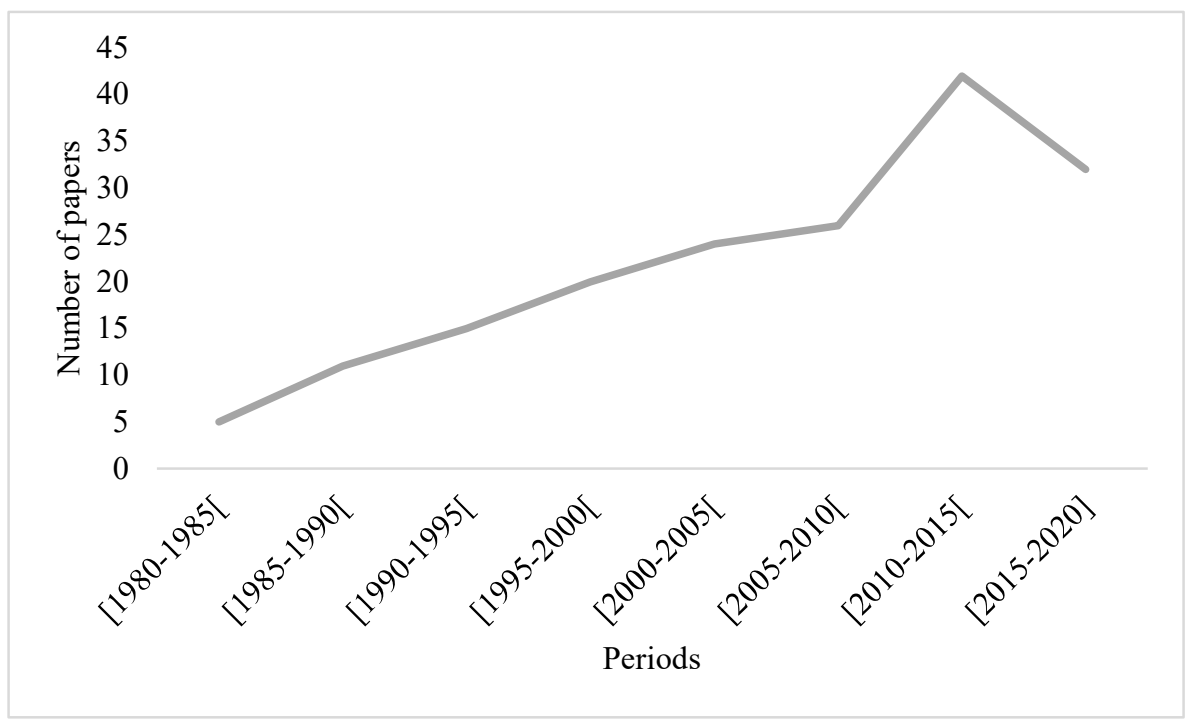

Figure 4. Temporal variation in the number of publications on tigernut over the world. 


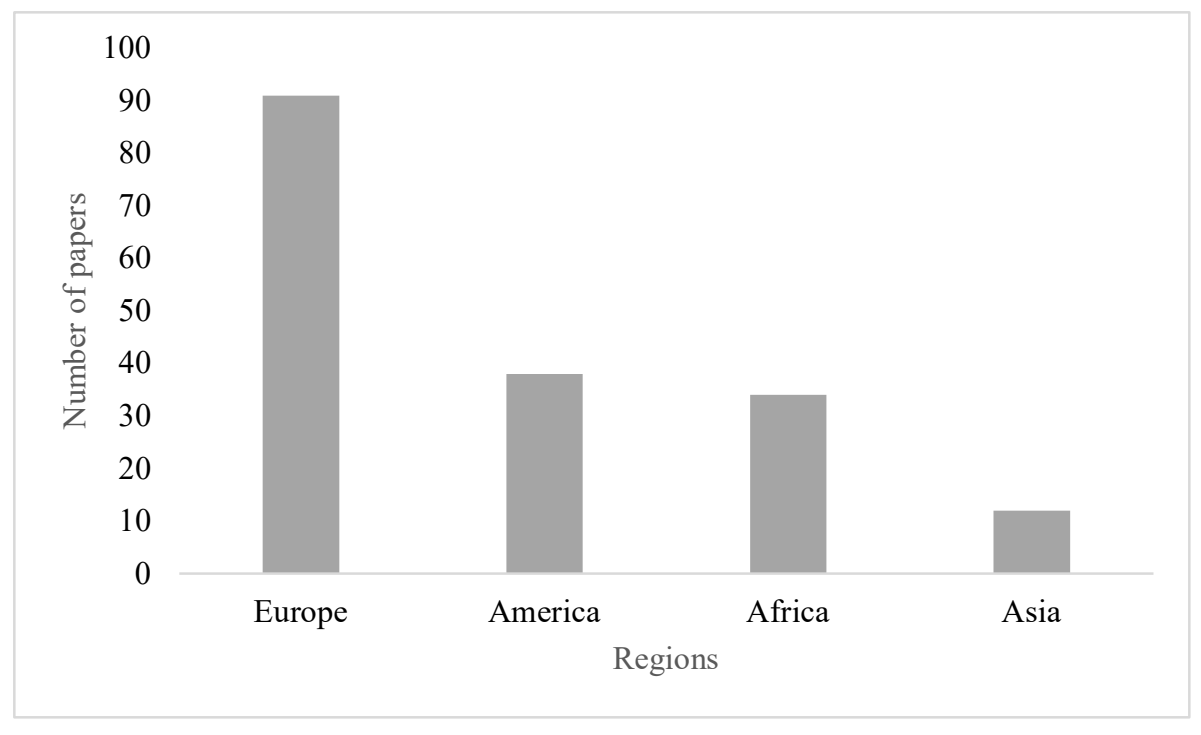

Figure 5. Number of publications recorded on biology, production constraints and uses of tigernut per region

\subsection{Biology of tigernut}

\subsubsection{Systematic classification of tigernut}

Tigernut (Cyperus esculentus L.), is a crop of perennial rhizomatous herbaceous plant of type $C 4$, belonging to the sedge (Cyperaceae) family [25, 26, 27]. Its taxonomic classification is as follows: Kingdom: Plantae; Subkingdom: Tracheobionta; Superdivision: Spermatophyta; Division: Magnoliophyta; Class: Liliopsida; Subclass: Commelinidae; Order: Cyperales; Family: Cyperaceae; Genus: Cyperus L; Species: Cyperus exculentus L. Synonym names of $C$. exculentus are: Chlorocyperus aureus Palla, Chlorocyperus phymatodes (Muhl.) Palla, Cyperus aureus Ten., Cyperus fulvescens Liebm., Cyperus phymatodes Muhl., Cyperus repens Ell., Cyperus tuberosis Pursh. [28]. Varieties of C. exculentus were; Cyperus esculentus var. hermannii (Buckley) Britton; Cyperus esculentus var. esculentus L.; Cyperus esculentus var. macrostachyus Boeckeler; Cyperus esculentus var. leptostachyus Boeckeler; Cyperus esculentus var. sativus Boeckeler. Cyperus esculentus is a diploid species, described as having $2 \mathrm{n}=$ ca. 48 in Canada by Mulligan and Junkins [16]. In contrast, Hicks [29] reported $2 \mathrm{n}=\mathrm{ca}$. 108 for plants collected in Boston, Massachusetts (USA).

\subsubsection{History and botanical description of C. esculentus}

Tigernut was one of the oldest cultivated plant species in prehistoric era and was considered as an important food. Roots of wild chufa were found at Wadi Kubbaniya, north of Aswan, dating to around 16,000 BC [30]. Dry tigernut tubers also appear later in tombs of the Predynastic period, around 3000 BC. During that period, tigernut tubers were consumed either boiled in beer, roasted, or as sweets made of ground tubers with honey [31]. It was also used as medicinal plant species and taken orally, as an ointment, or as an enema. Its use in fumigants to sweeten the smell of homes or clothing has also been reported by Defelice [17]. The tomb of the vizier Rekhmire from the 15th century $\mathrm{BCE}$, shows peasants preparing and measuring tiger nuts. 
Tigernut species is an annual or perennial plant, growing to $90 \mathrm{~cm}$ tall, with solitary stems growing from a tuber. The tigernut plant species is reproduced in three ways: by seeds, by creeping rhizomes, and by tubers [32-34]. The first tigernut leaves are linear, with a sharp wedge at the top, 2 to $10 \mathrm{~cm}$ long and $4 \mathrm{~mm}$ wide. The blade section forms a wide V. At the base of the leaf blade is a short trigonal sheath. The leaves are arranged tristically. The seedling can be connected to a mother plant by a rhizome or isolated. In adulthood, the port of tigernut appears in tuft formed by the interlocking of the leaf sheaths in a tristic manner. Each tuft only develops a single upright flowering axis. A mother plant is connected to child plants by superficial rhizomes. Roots were fasciculated, simple, threadlike and very numerous, forming a large root hairline. The underground apparatus of tigernut is characterized by the presence of a spherical and black mother tuber at the base of the main axis. The mother plant also develops deeper rhizomes measuring up to $1 \mathrm{~cm}$ in diameter with a sweet odor and sweet taste very popular with rats. Tigernut is wind pollinated and requires cross pollination as it is self-incompatible.

\subsubsection{Distribution and ecology of tigernut}

Tigernut is a crop widespread across much of the world. Distribution area take into account Africa with Madagascar, Southern Europe, as well as the Middle East and the Indian subcontinent. Distribution countries of tigernut crop were Nigeria, Morocco, Ivory Coast, Sudan, South Sudan, Gambia, Guinea Bissau, Ghana, Niger, Burkina Faso, Togo, Benin, Cameroon, Mali, United States, Saudi Arabia, Oman, Iran, Iraq, Guatemala, Mexico, Chile, Brazil, Lebanon, Syria, Jordan, Pakistan, India, Yemen [35-37].

Tigernut is a moisture loving species that grows near water. Its cultivation requires a mild climate with a low temperature, and reasonable photoperiod (12 to 14 hours/day). Light intensity can inhibit its flowering. Tuber initiation is also inhibited by other factors such as high levels of nitrogen, and high levels of gibberellic acid (USGS Weeds 2003). Tigernut is able to tolerate many adverse soil conditions such as periods of drought and flooding and survive soil temperatures around $-5^{\circ} \mathrm{C}\left(23^{\circ} \mathrm{F}\right)$. It prefer sandy soil with a $\mathrm{pH}$ between 5.0 -7.5 [38]. According to Hoffmann et al. [39], the germination rate of tubers depends both on the substrate and on their weight. They do not tolerate salinity. A single plant can form several thousand tubers per season under non-competitive conditions [38]. Tubers each contain many buds and can germinate several times before the food supply runs out. A main plant from an initial tuber can produce 36 secondary plants and 339 secondary tubers in 16 weeks of vegetation [38].

\subsubsection{Genetic diversity}

There is a considerable diversity of climatic, genetic, habitat, morphological adaptation among weed varieties of tigernut [40]. Taxonomists proposed several intraspecific divisions of the species based primarily on variations in floral structure [41]. The classification of the most widespread family recognizes four wild varieties of C. esculentus (esculentus, leptostachyus Boeckeler, macrostachyus Boeckeler and hermanii (Buckley) Britton) and a cultivated variety (sativus Boeck) not distinguished by some authors of var. esculentus from which it is derived by selection [42] (Schippers et al. 1995). Cyperus esculentus is a diploid species, described as having $2 \mathrm{n}=\mathrm{ca} .48$ by Mulligan and Junkins [16] based on Canadian populations while Hicks [29] reported $2 n=c a .108$ for plants collected in Boston. Basing on the morphological characters of seeds, Cyperus esculentus would include two distinct varieties in Niger according to the size of the tubers including the large and the small with several cultivars designated according to the producer [43]. In Nigeria, three varieties (black, brown and yellow) are cultivated [44]. Among these, only two varieties, yellow and brown are readily available in the market (Figure 6). The yellow variety is most preferred because of its inherent properties like its bigger 
size, attractive color and fleshier body [45]. Generally, yellow tigernut is most recognized and preferred in all distribution ranges of tigernut.

Based on genetic tools, the genetic study lead by Okoli et al. [40] on genetic diversity of yellow nutsedge using RAPD markers, showed a wide range of variation. The RAPD technique revealed a far greater level of variation in nine Californian samples. Abad et al. [41] using the same technique, found a high level of genetic variability among the clones tested, particularly among the cultivated ones. The study of genetic diversity must be deepened with the use of microsatellite markers, especially in Africa where current studies are essentially based on morphological characteristics. Researches that address morphological characterization, especially fruit and its subsequent components should be undertaken to complement existing knowledge systems of tigernut for future conservation purposes in Africa. Further studies should also examine the role of environmental conditions in driving phenotypic trait variation in C. exculentus. These research have to be completed with molecular genetic studies using more specific molecular markers for assessing genetic diversity in C. exculentus as contribution to enhance the selection of germplasm for conservation purposes.

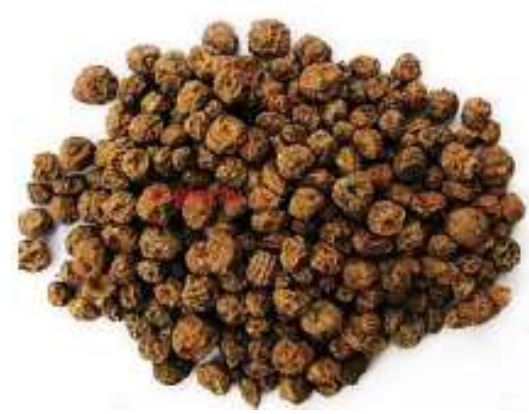

Big

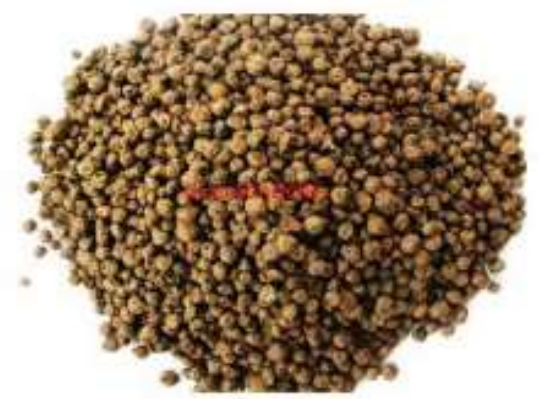

Yellow

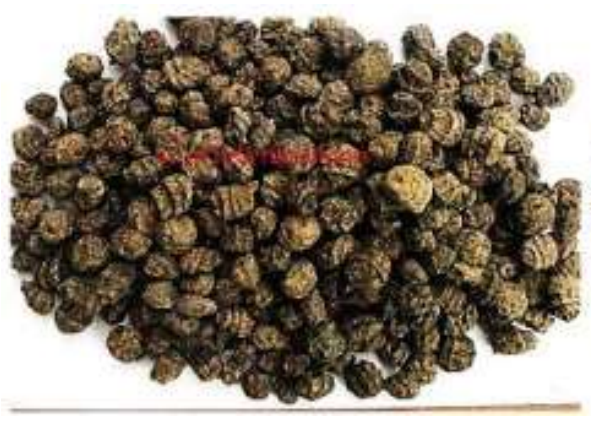

Big

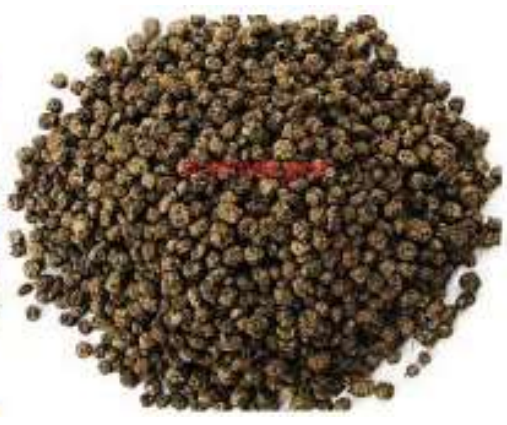

black

Figure 6. Tigernuts varieties cultivated in Nigeria (Umerie et al. 1997).

\subsection{Uses of tigernut}

The use of tigernut is made in several fields such as food, biofuel, cosmetics, fishing and fish breeding, medicine and pharmacology.

\subsubsection{Food uses}

Many studies have shown food importance of tigernut tubers over the world [46, 47]. Among 175 papers synthesized, 83 (43.42\%) dealt with food importance of tigernut tubers. Most of these papers were carried out in Europe. Tigernut tubers can be eaten raw, 
dried, roasted, and baked or be made into a refreshing milk beverage [15, 48, 49]. Tigernut tubers has a particular sweet that is found to be ideal for use in the baking industry [50]. It can be used to make delicious biscuits and cakes and also as component of fruit flavors [35, 51,52]. Tigernut tubers are chewed like sweets, or made into highly cherished milk like beverage referred to as "Atadwe milk" [24]. Fresh tubers are fermented to produce a local alcoholic beverage (Bannina et al. 2001) or as a seasoning to meat [53]. Food contains various compositions of antinutrients and nutrients and could have important or deleterious effects in the body when consumed. Tigernuts tuber oil contains about $18 \%$ saturated fatty acids (palmitic acid and stearic acid) and about $82 \%$ unsaturated fatty acids (oleic acid: omega 9, and linoleic acid: omega 6) [54-59]. This olive oillike composition shows that tigernut tuber oil is a potential substitute for it $[54,59]$. Rats fed a diet based on this oil showed an increased growth rate, and reduced lipid accumulation in vital organs, competitively with those fed soybean oil [60]. Tigernut seed feed could be part of a complete diet for animals, in that it provides both protein and energy supplements. Experiments on dwarf goats from West Africa [61], reported better performance in weight gain and feed efficiency in animals. According to Ikpeme et al. [62], tigernut tubers can be mixed with soybeans to traditionally produce adoptable and inexpensive infant (weaning) flour. The evaluations carried out on the nutritional and sensory characteristics of several formulas have shown that the STF3 formula (Tigernut: $55 \%$, soya: $35 \%$, powdered milk: $10 \%$ ) compares favorably with the commercial brand (made from corn, powdered milk, soybeans and additives). This crop, which is underused in sub-Saharan Africa, could therefore be used to sustainably reduce malnutrition and contribute to reach out the third goal of Sustainable development (Good health and well-being).

Tigernut are used to prepare a refreshing sweet drink known as "horchata de chufa" that means tigernuts milk, or more tigernuts orgeat. Tigernut tubers are a good source of starch (comparable to corn) and a potential biomaterial for industrial uses. Indeed, the comparison of the physicochemical properties of tigernut tuber starch with the standards for industrial corn starch, has shown that the two types of starch compare favorably [63]. Cow's milk yogurt and the composite (cow's milk + tigernuts milk) were rated similar in almost all quality attributes, indicating the possibility of adding tigernuts milk to cow's milk in nutrient production and inexpensive yogurts [64]. C. exculentus is a highly valued crop species which is widely used for food purposes [58, 59, 65]. Owing to its high nutritional benefit, and local availability, the promotion of this species can substantially contribute to reduce malnutrition caused by lack of micronutrients in Africa and reach out the Sustainable Development Goals related to poverty, zero hunger and well-being.

\subsubsection{Medicinal properties}

59 papers (33.71\%) dealt with medicinal properties of tigernut. Most of these papers focused on traditional and pharmacological uses of tigernut in Africa. There are many papers which dealt with both food use and medicinal properties (22.78\%). Tigernut seeds are used medicinally as digestive tonic, having a heating and drying effect on digestive system and alleviating flatulence and also promote urine production and menstruation [66]. They are also used in the treatment of flatulent, in digestion, diarrhea, dysentery, colic, debility and excessive thirst $[18,67]$. Tigernut was reported as healthy and helps in preventing heart, thrombosis and activates blood circulation. Phytochemicals like alkyloids, phenols, flavonoids, glycosides, have been found in tubers of tigernut [68]. This testifies to the medicinal importance of the species in the practices of traditional medicine. Tigernut tuber extracts possess antimicrobial and antioxidant properties, and can thus be used in the treatment of diseases involving the growth of cells or tumors. Oils extracted from Cyperus rotundus and Cyperus esculentus exhibit strong antiinflammatory and anti-convulsant activities [69]. Furthermore, methanolic extracts of 
nutsedge significantly increased, in a dose-dependent manner, the parameters of gonadotropins, testosterone and sperm in rats. This observation justifies the role of improving reproductive functions of C. rotundus [70] and C. esculentus [71] in traditional medicine. Tigernut tuber tubers help prevent heart attacks, thrombosis and colon cancer [72, 73], and are beneficial for diabetics and those seeking to lower cholesterol or lose weight [74]. Given its medicinal potential, we suggest that further research address the ethnopharmacological benefits to ensure the development of standardized phytomedicines from the species. Hence, detailed studies of biological activities and toxicity in C. exculentus could help to clarify this perspective.

\subsubsection{Cosmetic uses}

Tigernut vegetable oil is obtained by first cold pressing of its tubers. This product is traditionally used to limit hair regrowth. Tigernuts vegetable oil is very nourishing, it protects the skin and hair from dehydration [75]. Its vitamin E content gives it antioxidant properties, thus protecting the skin from premature aging. It improves the elasticity of the skin, revitalizes and restores radiance and vigor to damaged hair. The physicochemical properties of this edible oil show an interest for its use in soap [75].

\subsubsection{Biofuel use}

Few studies identified the use of tigernut as a source of biofuel. 25 papers $(14.28 \%)$ dealt with biofuel property of tigernut. Majority of these papers came from Nigeria $(16 / 25)$. Since tubers containing $20-35 \%$ oil $[17,49,76,73]$, tigernut was considered as a potential oilseed crop for biodiesel production [77-79]. Barminas et al. (2001) carried out preliminary studies on the transesterification of nutsedge as a source of biofuel. Also, Ugheoke et al. [80] studied the optimization of the transesterification process of tigernut oil for the biodiesel production, specifically to determine the optimum concentration level of the catalyst that gives maximum yield of methyl ester. The authors found $0.9 \%$ weight (in gram) of catalyst per volume of transesterified tigernut oil and it gave a biodiesel yield fraction of 0.67 . According to Ofoefule et al. [81] the yield of biodiesel is $82 \%$, and its mixture with petro-diesel, in addition to being good for biodiesel engines, would also be suitable for engines which are not specifically designed for the use of biodiesels. Tigernut deserves as much attention as other sources of biodiesel. Up to now, studies related to the use of $C$. exculentus as a source of biofuel are unwell documented. Next studies related to this field can boost the valorization of the species and the promotion of its uses in Africa

\subsubsection{Fishing and fish breeding}

Few studies (5 papers) investigated the use of tigernuts in the fishing. These papers were showed the use of tigernut as a bait for carp and as food $[2,68]$. The boiled nuts are used in as a bait for carp (Cyprinidae). However, it should be prepared for about 24-48 hours to avoid damaging the fish. Otherwise, it can be extremely toxic to them. Experiments with Clarias gariepinus have shown that tigernut seed is a suitable substitute for maize in the diet of the species $[82,83]$. This is explained by the proximity of the physicochemical properties of corn starch and that of tigernuts. Thus, tigernuts can be used in fish farming, replacing corn, to reduce the cost of production. Of course, this replacement should not exceed 50\% inclusion for good production of C. gariepinus [84]. In addition, reducing the cost of production improves the profitability of the activity, and therefore the income of producers. However, the fall in the price of fish that will follow, will ensure nutritional security by improving the financial accessibility of the product.

\subsection{Production constraints and solution approaches}


The constraints of tigernut production were not yet well documented. Through this review, only five paper were recorded [9, 13, 85-87]. However, there are several papers that treat tigernut as a noxious adventis plant. Tigernut production constraints were specifically related to culture and post-harvest storage. The main constraints linked to tiger nut cultivation are: insufficient mineral fertilizers, difficult harvesting and marketing of tiger nuts [9]. C. esculentus is extremely difficult to remove completely once established. This is owing to the plant having a stratified and layered root system, with tubers and roots being interconnected to a depth of $36 \mathrm{~cm}$ or more. The tubers are connected by fragile roots that are prone to snapping when pulled, making the root system difficult to remove intact. Tigernut tubers are harvested about 2 to 3 months after sowing, depending on soil fertility and moisture availability. The tubers are harvested about 2 to 3 months after sowing, depending on soil fertility and moisture availability. The maturity is marked by the yellowing of the leaves. Mature plants are dug up and the tubers detached by hand. This process leaves a large number of tubers in the ground, which are slowly and painfully picked individually. This requires a large workforce. Usually, producers use hired labor for the harvest $[9,13]$. A crop improvement strategy should take into account the development of varieties with thicker and relatively short runners, which will not easily break during harvest. After harvest, tubers intended for sale are properly washed and / or dried before storage. During storage, tubers tend to lose viability or rot quickly. This could be explained by the fact that washing bruises the tubers and creates entry points for pathogenic organisms to infect them. Sustainable conservation methods must be considered in order to gain post-harvest losses which may increase the income of farmers.

For a good conservation and valorization program of tigernut, the development of tigernut varieties with short and robust runners that do not come off easily during harvest should be considered by breeding programs. In addition, measures must be taken to overcome the irregularity of the rains caused by climate change, which is to some extent a constraint on its production. Since the harvesting is usually manual, the development of low- cost technologies allowing a quick collection of tigernut tubers would facilitate harvest and postharvest operations.

\subsection{Research topic}

Research needs on the tigernut (neglected and underutilised crop species) in Africa were:

- Ethnobotanical investigation and documentation of the indigenous knowledge,

- Identification and prioritization of the production constraints,

- Agro-morphological characterization and genetic diversity analysis,

- Improvement of the agricultural practices and documentation of the pests and diseases,

- Agronomic (yield, biotic and abiotic stresses) evaluation,

- Assessment of the seeds quality and conservation,

- Improvement of postharvest conservation and processing technologies,

- Study of the value chains and assessment of the contribution to household income,

- Germplasm collection and conservation. 


\subsection{Strengths and limitations}

The review shows the importance of screening the available literature in identifying research gaps with ways forward to sustain the current research efforts on the valorization of Neglected and Underutilized Crop Species. However, it may have its own weaknesses owing to publication bias that could be derived from search results and thus any such bias may have been transferred to the present review. Besides, a large body of recorded papers included in this systematic review did not cover certain aspects such as biochemical, mineral and vitamin composition, biological activities etc., which are worth addressing and discussing, especially for plant genetic resources.

\section{Conclusion}

This systematic review provides insights into the biology, production constraints and uses of Tigernut through broad cross-disciplinary perspectives in the world. Cyperus exculentus is a Neglected/Underutilized Crop Species weakly studied in Africa. The review brought out several gaps in the knowledge of C. exculentus. It showed an increased number of scientific papers in the species in these two last decades. Tigernut has been better studied in Europe, America that Africa. Within Africa, West Africa has obtained more scientific works dealing with $\mathrm{C}$. exculentus than others sub-regions. This tendency reflects a heterogeneous and uneven distribution of publications about C. exculentus across its distribution range. Thus, the review summarizes previous findings and supports the general assumption that the number of publications on biological resources depends on their potential economic value, conservation and valorization status, and strength of scientific research (Juarez-Orozco et al. 2017, Houndonougbo et al., 2020). Studies relate to genetic diversity, production constraint and valorization have been weakly recorded while those relate to the use of the species have been well documented.

\section{Acknowledgments}

The authors are grateful to anonymous reviewers for their constructive comments and suggestions.

Disclosure statement

No potential conflict of interest was reported by the author(s).

Funding No funds, grants, or other support was received

\section{Conclusions}

This systematic review provides insights into the biology, production constraints and uses of Tigernut through broad cross-disciplinary perspectives in the world. Cyperus exculentus is a Neglected/Underutilized Crop Species weakly studied in Africa. The review brought out several gaps in the knowledge of $C$. exculentus. It showed an increased number of scientific papers in the species in these two last decades. Tigernut has been better studied in Europe, America that Africa. Within Africa, West Africa has obtained more scientific works dealing with $\mathrm{C}$. exculentus than others sub-regions. This tendency reflects a heterogeneous and uneven distribution of publications about C. exculentus across its distribution range. Thus, the review summarizes previous findings and supports the general assumption that the number of publications on biological resources depends on their potential economic value, conservation and valorization status, and strength of scientific research (Juarez-Orozco et al. 2017, Houndonougbo et al., 2020). Studies relate to genetic diversity, production constraint and valorization have 
been weakly recorded while those relate to the use of the species have been well documented.

Author Contributions: GCA. (Ghislain Comlan Akabassi), K.K.P. and E.A.P. (Elie Antoine Padonou) wrote the paper. All authors have read and agreed to the published version of the manuscript.

Acknowledgments: In this section, you can acknowledge any support given which is not covered by the author contribution or funding sections. This may include administrative and technical support, or donations in kind (e.g., materials used for experiments).

Conflicts of Interest: The authors declare no conflict of interest.

\section{References}

1. Magbagbeola, J.A.O., Adetoso, J.A., Owolabi, O.A. Neglected and underutilized species (NUS): a panacea for community focused development to poverty alleviation/poverty reduction in Nigeria. Journal of Economics and International Finance 2010, 2, 208-211. t http://www.academicjournals.org/IEIF

2. Dansi, A., Vodouhè, R., Azokpota, P., Yedomonhan, H., Assogba, P., Adjatin, A., Akpagana, K. Diversity of the neglected and underutilized crop species of importance in Benin. The scientific world journal, 2012, 19 p. https://doi.org/10.1100/2012/932947

3. Food and Agriculture Organization (FAO). Sustainable Land Management (SLM) in practice in the Kagera Basin. Lessons learned for scaling up at landscape level - Results of the Kagera Transboundary Agro-ecosystem Management Project (Kagera TAMP). Food and Agriculture Organization of the United Nations, Rome, Italy 2017, $440 \mathrm{p}$

4. Johns, T., Eyzaguirre, P.B. "Symposium on "wild- gathered plants: basic nutrition, health and survival” Linking biodiversity, diet and health in policy and practice," Proceedings of the Nutrition Society 2006, 65, 182189.

5. Ghane, S.G., Lokhande, V.H., Ahire, M.L., Nikam, T.D. Indigofera glandulosa Wendl. (Barbada) a potential source of nutritious food: underutilized and neglected legume in India. Genetic Resources and Crop Evolution 2010, 57, 147-153. https://doi.org/10.1007/s10722-009-9496-1

6. Tetteh, J.P., Ofori, E. A baseline survey of tiger nut (Cyperus esculentus) production in the Kwahu South District of Ghana. Ghana Journal of Agricultural Science 1998, 31, 211-216

7. Cortés, C., Esteve, M.J., Frigola, A., Torregrosa, F. Quality characteristics of horchata (a Spanish vegetable beverage) treated with pulsed electric fields during shelf-life. Food Chemistry 2005, 91, 319-325. https://doi.org/10.1016/j.foodchem.2004.06.014

8. Aly, D., Dah-Dovonon, Z.J., Dansi, A. Deuxième rapport sur l'état des ressources phytogénétiques pour l'alimentation et l'agriculture au Bénin. Ministère de l'Agriculture de l'Elevage et de la Pêche 2007, 59p.

9. Bori, H., Toudou, O., Adamou, M.D.M., Moumouni Dan Mairo, T. La culture de souchet (Cyperus esculentus) au Niger: Origine, atouts et contraintes. Journal of Animal \& Plant Sciences 2018. 37, 5997-6007. http://www.m.elewa.org/JAPS

10. Aoua, D., Dramane, K., Fatoumata, K., Mady, S. Appui au développement de la chaîne de valeur du pois sucré à Farakala, Sikasso-Mali 2008, 12p.

11. Dodet, M. Diversité Génétique et Phénologie de Cyperus esculentus L. (Cyperaceae) pour une Gestion Intégrée de l'Espèce dans les Cultures de Haute Lande. Thèse de doctorat. Université de Bourgogne 2006, 224p.

12. De Castro, O., Gargiulo, R., Del Guacchio, E., Caputo, P., De Luca, P. A molecular survey concerning the origin of Cyperus esculentus (Cyperaceae, Poales): two sides of the same coin (weed vs. crop). Annals of botany, 2015, 115, 733-745. https://doi.org/10.1093/aob/mcv001

13. Sakatai, D.P., Bouba, A.A., Bassala, J.P.O., Balna, J., Palou, O., Bourou, S. Valorisation de quatre accessions de souchets (Cyperus esculentus L.): une bonne option de diversification de culture pour les producteurs de la localité de danay-vokgora 
(Mayo-danay) en zone soudano-sahélienne du Cameroun. International Journal of Biological and Chemical Sciences 2020, 14, 2277-2293. https://DOI:10.4314/ijbcs.v14i6.28

14. Alobo, A.P., Ogbogo, P.O. Selected Properties of Tigernut Starch as Affected by Physical and Chemical Modification. Proceedings of the $31^{\text {st }}$ Annual NIFST Conference, Abuja, Nigeria. 22-25th October 2007.

15. Oladele, A.K., Aina, J.O. Chemical composition and functional properties of flour produced from two varieties of tigernut (Cyperus esculentus). African Journal of Biotechnology 2007, 6. https://doi.org/10.5897/AJB2007.000-2391

16. Mulligan, G.A., Junkins, B.E. The biology of Canadian weeds. 17. Cyperus esculentus L. Canadian Journal of Plant Science 1976, 56, 339-350. https://doi.org/10.4141/cjps76-052

17. Defelice, M.S. Yellow Nutsedge Cyperus esculentus L.-Snack Food of the Gods1. Weed Technology 2002, 16, $901-907$. https://doi.org/10.1614/0890-037X(2002)016[0901:YNCELS]2.0.CO;2

18. Chavallier, A. The encyclopidia of medicinal plants. Dorling Kindersley, London 1996.

19. Groombridge, B. Global Biodiversity status of the Earth's living Resources, London Chapman and Hall. 1992,350 - 355.

20. Zohary, D., Hopf, M. Domestication of plants in the Old World, third edition Oxford University Press 2000, $198 \mathrm{p}$

21. Dutta, A.C. Botany for Degree students (5th Edition). Oxford University Press, London, 752-780.

22. Harden, C.L., Meador, K.J., Pennell, P.B., Allen Hauser, W., Gronseth, G.S., French, J.A., Le Guen, C. Management issues for women with epilepsy - Focus on pregnancy (an evidence-based review): II. Teratogenesis and perinatal outcomes: Report of the Quality Standards Subcommittee and Therapeutics and Technology Subcommittee of the American Academy of Neurology and the American Epilepsy Society. Epilepsia 2009, 50, 1237-1246. https://doi.org/10.1111/j.15281167.2009.02129.x

23. Barminas, J.T., Maina, H.M., Tahir, S., Kubmarawa, D., Tsware, K. A preliminary investigation into the biofuel characteristics of tigernut (Cyperus esculentus) oil. Bioresource technology 2001, 79, 87-89. https://doi.org/10.1016/S0960-8524(01)00026$\underline{8}$

24. Obeng-Koranteng, G., Kavi, R.K., Bugyei, K.A., Anafo, P. Information sources used by tiger nut (Cyperus esculentus) farmers for improved sustainable agriculture development in Aduamoa Ghana. J Sustainable Dev. Africa 2017, 19, 84- 102

25. Wills GD. Description of Purple and Yellow Nutsedge (Cyperus rotundus and C. esculentus). Weed Technology 1987, 1, 2-9. https://www.jstor.org/stable/3986970

26. Li, M., Wedin, D.A., Tieszen, L.T. C3 and C4 Photosynthesis in Cyperus (Cyperaceae) in Temperate Eastern North America. Can. J. Bot. 1999, 77, 209-218. https://DOI:10.1139/cjb-77-2-209

27. Judd, C, Kellog \& Stevens. Relations Phylogéniques entre les Angiospermes. Botanique Systématique - Une perspective phylogénétique. De Boeck Université 2002, 1ère édition, 210-216.

28. Global Invasive Species Database. Cyperus exculentus, http://www.issg. or/database/ species/ ecology.asp?si=1448 [May, 18 2021]

29. Hicks, G.C. Cytological Studies in Cyperus, Eleocharis, Dulichium and Eriophorium. Bot. Gaz. 1929, 88: 132-149. https://doi.org/10.1086/333986

30. Sanderson, H. Prance, Ghillean, Nesbitt, Mark (eds.). The Cultural History of Plants. Routledge 2005, p. 74. ISBN 0415927463.

31. Moshe, N. A sweetmeat plant, a perfume plant and their weedy relatives: A chapter in the history of Cyperus esculentus L. and C. rotundus L. Economic Botany 1992, 46, 64-71. https://doi.org/10.1007/BF02985255

32. Stoller, E.W. Yellow Nut Sedge: A Menance in the Corn Belt (No. 1642). US Department of Agriculture, Agricultural Research Service 1981.

33. Renne, I.J., Tracy, B.F. Disturbance persistence in managed grasslands: shifts in aboveground community structure and the weed seed bank. Plant Ecology 2007, 190, 71-80. https://doi.org/10.1007/s11258-006-9191-7

34. Oldfield Callie, A., Evans, J.P. "Twelve years of repeated wild hog activity promotes population maintenance of an invasive clonal plant in a coastal dune ecosystem". Ecology and Evolution 2016, 6, 2569-2578. https://doi:10.1002/ece3.2045 
35. Sánchez-Zapata, E., Fernández-López, J., Pérez-Alvarez, J.A. "Tiger Nut (Cyperus esculentus) Commercialization: Health Aspects, Composition, Properties, and Food Applications". Comprehensive Reviews in Food Science and Food Safety 2012, 11, 366-377. https://doi:10.1111/j.1541-4337.2012.00190.x

36. Biota of North America Program county distribution map 2013. http://bonap.net/Map Gallery/County/Tradescantia\%20spathacea.png,

37. World Checklist of Selected Plant Families: Royal Botanic Gardens, Kew". Kew Science. Retrieved May 5, 2021.

38. USGS Weeds in the West project. Status of introduced Plants in Southern Arizona Parks, Factsheets for Cyperus esculentus L., Tucson, Arizona 2003.

39. Hoffmann, Z.P., Buzsáki, K., Béres, I. Spreading and germination of yellow nutsedge (Cyperus esculentus L.) in Hungary. Communications in agricultural and applied biological sciences 2006, 71, 797-801.

40. Okoli, C.A.N., Shilling, D.G., Smith, R.L., Bewick, T.A. Genetic Diversity in Purple Nutsedge (Cyperus rotundus L.) and Yellow Nutsedge (Cyperus esculentus L.). Biological control 1997, 8, 111-118. https://doi.org/10.1006/bcon.1996.0490

41. Abad, P., Pascual, B., Maroto, J.V., López-Galarza, S., Vicente, M.J., Alagarda, J. RAPD analysis of cultivated and wild yellow nutsedge (Cyperus esculentus L.). Weed Science 1998, 46, 319-321. https://www.jstor.org/stable/4045868

42. Schippers, P., Ter Borg, S.J., Bos, J.J. A revision of the infraspecific taxonomy of Cyperus esculentus (yellow nutsedge) with an experimentally evaluated character set. Systematic Botany 1995, 461-481

43. Toukoua, D., Sidikou, D., Ibrahim, A., Badagé, G. Plan d'action sur la filière souchet. Rapport de consultation au PPEAP 2002. $57 \mathrm{p}$

44. Umerie, S.C., Okafor, E.P., Uka, A.S. Evaluation of the tubers and oil of Cyperus esculentus. Bioresources Technology 1997, 6, 171 - 173. https://doi.org/10.1016/S0960-8524(97)00045-X

45. Belewu, M.A., Abodunrin, O.A. Preparation of Kunnu from unexploited rich food source: Tiger nut (Cyperus esculentus). World Journal of Dairy and Food Sciences 2006, 1, 19-21. http//: https://doi.org/10.3923/PJN.2008.109.111

46. Bamishaiye, E.I., Bamishaiye, O.M. Tiger nut: as a plant, its derivatives and benefits. African Journal of Food, Agriculture, Nutrition and Development 2011, 11, 5157-5170. http//:doi.10.4314/ajfand.v11i5.70443

47. Pascual-Seva, N., San Bautista, A., López-Galarza, S.V., Maroto, J.V., Pascual, B. 'Alboraia'and 'Bonrepos': The first registered Chufa (Cyperus esculentus L. var. sativus Boeck.) cultivars. HortScience 2013, 48, 386-389. https://doi.org/10.21273/HORTSCI.48.3.386

48. Mordi, J.I., Okafor, J.N.C., Ozumba, A.U., Solomon, H.M., Olatunji, O. Contaminants and defects in Nigerian Tiger-nut varieties. Tropical Science 2006, 46, 141-142. https://doi.org/10.1002/ts.71

49. Salau, R.B., Ndamitso, M.M., Paiko, Y.B., Jacob, J.O., Jolayemi, O.O., Mustapha, S. Assessment of the proximate composition, food functionality and oil characterization of mixed varieties of Cyperus esculentus (Tiger nut) rhizome flour. Continental Journal of Food Science and Technology 2012, 6, 13-19. https://doi:10.5707/cjfst.2012.6.2.13.19

50. Gambo, A., Da'u, A. Tiger nut (Cyperus esculentus): composition, products, uses and health benefits-a review. Bayero journal of pure and applied sciences 2014, 7, 56-61. https://DOI:10.4314/bajopas.v7i1.11

51. Bonanome, A., Grundy, S.M. Effect of dietary stearic acid on plasma cholesterol and lipoprotein levels. New England Journal of Medicine 1988, 318, 1244-1248. https://doi.org/DOI:10.1056/NEJM198805123181905

52. Adgidzi, E.A., Ingbian, E.K., Abu, J.O. Effects of hot water and steam blanching on the quality of aqueous extract from tigernuts (Cyperus esculentus). Product Agric. Tech 2011, 7, 90-102. www.patnsukjournal.net/currentissue

53. Killinger, G.B., Stokes, W.E. Chufas in Florida. University of Florida Agricultiral Experiment Station Bulletin 1946, $\mathrm{n}^{\circ} .419$, $16 \mathrm{p}$

54. Bosch, L., Alegria, A., Farre, R. RP-HPLC determination of tiger nut and orgeat amino acid contents. Food science and technology international 2005, 11, 33-40. https://doi.org/10.1177/1082013205051266 
55. Dubois, V., Breton, S., Linder, M., Fanni, J., Parmentier, M. Fatty acid profiles of 80 vegetable oils with regard to their nutritional potential. European Journal of Lipid Science and Technology 2007, 109, 710-732. https://doi.org/10.1002/ejlt.200700040

56. Arafat, S.M., Gaafar, A.M., Basuny, A.M., Nassef, S.L. Chufa tubers (Cyperus esculentus L.): As a new source of food. World Applied Sciences Journal 2009, 7, 151-156.

57. Chinma, C.E., Adewuyi, O., Abu, J.O. Effect of germination on the chemical, functional and pasting properties of flour from brown and yellow varieties of tigernut (Cyperus esculentus). Food Research International 2009, 42, 1004-1009. https://doi.org/10.1016/j.foodres.2009.04.024

58. Chukwuma, E.R., Obioma, N., Christopher, O.I. The phytochemical composition and some biochemical effects of Nigerian tigernut (Cyperus esculentus L.) tuber. Pakistan Journal of Nutrition 2010, 9, 709-715

59. Adejuyitan, J.A. Tiger nut processing: its food uses and health benefits. American Journal of Food Technology 2011, 6, 197-201. http://DOI:103923/ajft.2011.197.201

60. Bamishaiye, E. I., Muhammad, N. O., \& Bamishaiye, O. M. Assessment of biological value of tiger nut (Cyperus esculentus) tuber oil meal-based diet in rats. Annals of Biological Research 2010, 1, 274-280.

61. Belewu, M. A., and Belewu, K. Y. Comparative physico-chemical evaluation of tiger-nut, soybean and coconut milk sources. International Journal of Agriculture and Biology 2007, 5(785), e787.

62. Ikpeme-Emmanuel, C.A., Ekpeyoung, I.O., Igile, G.O. Chemical and protein quality of Soybean (Glycine max) and Tigernut (Cyperus esculentus) based weaning food. Journal of Food Research 2012, 1, 246. https://DOI:10.5539/JFR.V1N2P246

63. Kenneth, H. Y., Ricigliano, M., Hidalgo, M., Abou-Alfa, G. K., Lowery, M. A., Saltz, L. B., ... \& O'Reilly, E. M. Pharmacogenomic modeling of circulating tumor and invasive cells for prediction of chemotherapy response and resistance in pancreatic cancer. Clinical Cancer Research 2014, 20, 5281-5289.

64. Sanful, R.E. The use of tiger-nut (Cyperus esculentus), cow milk and their composite as substrates for yoghurt production. Pakistan Journal of Nutrition 2009, 8, 755-758. https://doi:10.1.1.558.6572

65. Wongnaa, C. A., \& Awunyo-Vitor, D. Achieving sustainable development goals on no poverty and zero hunger: Does technical efficiency of Ghana's maize farmers matter?. Agriculture \& Food Security 2018, 7, 1-13.

66. Aremu, M.O., Olaofe, O., Akintayo, E.T. A comparative study on the chemical and amino acid composition of some Nigerian underutilized legume flours. Pakistan Journal of Nutrition 2006, 5, 34 - 38. https://doi.10.1.1.586.6855

67. Aremu, M.O., Olonisakin, A., Opaluwa, O.D., Mohammed, Y., Salau, R.B. Nutritional qualities assessment of tilapia fish (Tilapia quinnesis). Indian Journal of Multidisciplinary Research 2007, 3, 443 - 465.

68. Oloyede, G.K., Abimbade, S.F., Nwabueze, C.C. Antioxidant and Toxicity Screening of Extracts obtained from Cyperus esculentus. Academia Arena 2014, 6, 77-83. http://www.sciencepub.net/academia.9

69. Biradar, S., Kangralkar, V.A., Mandavkar, Y., Thakur, M., Chougule, N. Antiinflammatory, antiarthritic, analgesic and anticonvulsant activity of Cyperus essential oils. Int J Pharm Pharm Sci 2010, 2, 123-5

70. Sivapalan, S.R. Medicinal Uses and Pharmacological Activities of Cyperus rotundus Linn - A Review. International Journal of Scientific and Research Publications 2013, 3, 1-8. https://doi:10.1.1.414.7378

71. Agbai, E.O., Nwanegwo, C.O. Luteinizing Hormone, Follicle Stimulating Hormone, Testosterone, Sperm Count and Motility in Male Albino Wistar Rats. Journal of Medical and Applied Biosciences 2013, 5, 52 - 61

72. Osagie, A.U., Eka, O.U. Nutritional Quality of Plant Foods. Post-harvest research unit, 1998, 22, 246-249.

73. Adejuyitan, J.A., Otunola, E.T., Akande, E.A., Bolarinwa, I.F., Oladokun, F.M. Some physicochemical properties of flour obtained from fermentation of tigernut (Cyperus esculentus) sourced from a market in Ogbomoso, Nigeria. African Journal of Food Science 2009, 3, 51-55. http://www.academicjournals.org/ajfs

74. Maton, A., Hopkins, J., McLaughlin, C.W., Susan, H., Warner, M.Q., LaHart, D., Jill, D. Human Biology and Health. Englewood Cliffs, New Jersey, USA: Prentice Hall. 1993. 
75. Ekeanyanwu RC, Ononogbu CI. 2010. Nutritive Value of Nigerian Tigernut (Cyperus esculentus L.). Agricultural Journal 2002, 5, 297-302. https://DOI:10.3923/aj.2010.297.302

76. Darnoko, D., Cheryan, M. Kinetics of palm oil transesterification in a batch reactor. Journal of the American Oil Chemists' Society 2000, 77, 1263-1267. https://doi.org/10.1007/s11746-000-0198-y

77. Batel, W., Graef, M., Meyer, G.J., Moller, R.., Schroedder, F. Pflonzenole fur die kraftstoff-und

78. Foidl, N., Foidl, G., Sanchez, M., Mittelbach, M., Hackel, S. Jatropha curcas L. as a source for the production of biofuel in Nicaragua. Bioresource technology 1996, 58, 77-82. https://doi.org/10.1016/S0960-8524(96)00111-3

79. Daniel, Z., Hopf, M. Domestication of plants in the old world, third edition, Oxford University Press, 2000, 198 p

80. Ugheoke, B.I., Patrick, D.O., Kefas, H.M., Onche, E.O. Determination of Optimal Catalyst Concentration for Maximum Biodiesel Yield from Tigernut (Cyperus esculentus) Oil. Leonardo Journal of Sciences, 2007, 6, 131-136. https://doi:10.1.1.513.4228

81. Ofoefule, A.U., Ibeto, C.N., Okoro, U.C., Onukwuli, O.D. Biodiesel Production from Tigernut (Cyperus esculentus) Oil and Characterization of its Blend with Petro-diesel. Physical Review \& Research International 2013, 3, 145-153

82. Oladele, A.K., Alatise, P.S., Ogundele, O. Evaluation of Tigernut (Cyperus esculentus) Meal as a Replacement for Maize Meal in the Diet of Catfish (Clarias gariepinus) Fingerlings. World Journal of Agricultural Sciences 2010, 6, 18-22. https://doi.org/10.1.1.415.587

83. Agbabiaka, L.A., Ezeafulukwe, C.F. Utilization of tigernut (Cyperus esculentus L.) meal as dietary supplement by African catfish (Clarias gariepinus Burchell, 1822). Fisheries and Aquaculture Journal 2013, 1-8. http://astonjournals.com/faj

84. Agbabiaka, L.A., Madubuiko, C.U., Anyanwu, C.N. Replacement Value of Tigernut Meal (Cyperus esculentus) with Maize in Catfish (Clarias gariepinus) Diets. Science Research Reporter 2012, 2, 130-134

85. INRAN. Deuxième rapport sur l'état des ressources phytogénétiques pour l'alimentation et l'agriculture, 2007, 71 p

86. ONG Peamuru. Le souchet: (Cyperus esculentus) une culture de rente très prometteuse dans la région de Maradi (Niger). Rapports d'enquête sur le souchet 2013, 2p. https://recaniger.org/IMG/pdf/Souchet_au_Niger_P EAMURU_light.pdf

87. Aka Boigny, A.A., Konan, N’Guessan, Y., Coulibaly, A., Chatigre Kouamé, O., Biego, G.H. Physico-chemical and nutritive properties of seeds and oil deriving from the sweet pea (Cyperus esculentus L.) marketed in Côte d'Ivoire. International Journal of Biochemistry Research \& Review 2016, 13, 1-9. http://DOI:10.9734/IJBCRR/2016/28217 